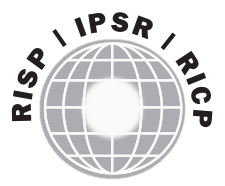

\title{
How the Military Competes for Expenditure in Brazilian Democracy: Arguments for an Outlier
}

\author{
Jorge Zaverucha and Flávio da Cunha Rezende
}

\begin{abstract}
Comparative analysts argue that democracies spend less on military policies than authoritarian states, a claim that was applied to Brazilian electoral democracy by Hunter (1997). In fact, Brazil behaves as an outlier and military spending has continued to increase since 1995. Our explanation for this behavior relies on the idea of internal political governability risks faced by Brazilian presidents. They are continually threatened by leftist groups that have fragile commitments to liberal democracies and they rely on the military to strategically protect them.
\end{abstract}

Keywords: Democratic peace $\bullet$ Democratization $\bullet$ Military expenditures

- Brazil • Political governability

\section{Introduction}

Democratic civilian control over the military may correlate with either low or high defense spending. Here, however, we are not dealing with consolidated democracies, but with countries in the process of democratization such as Brazil. The literature on democratic peace supposes that democratization usually leads to a reduction of military expenditure vis-à-vis social spending. It leaves open the question of under what conditions the transition from authoritarian regimes to democracy could lead to a reduction in military expenditure vis-à-vis social spending. ${ }^{1}$ In Brazil, the return to democracy did not cause the military to reduce their levels of spending either during the regime of Fernando Henrique Cardoso (FHC) or, thus far, under that of Luís Inácio da Silva (Lula). ${ }^{2}$ Comparative empirical data on budgets at the ministerial level for these two administrations provide strong support for the argument that Brazil is an outlier. ${ }^{3}$ In fact, the military continued to expand its expenditures vigorously following the return to democracy.

Although no one claims a direct causal relationship between regime type and military expenditure, there has been an often expressed supposition that democratization leads to a relative reduction of military expenditure because, with the return to electoral democracy, the military must compete with newly powerful 
social and political actors. Such competition may occur under conditions of expansion, maintenance, or reduction of total public expenditures. In Brazil, as shall be shown, the military continues to be competitive as a high spender in the context of a large expansion of social spending since 1994.

We are specifically interested in offering answers to the following questions: (a) What are the causal mechanisms that lead democratic institutions to produce high military spending in Brazil? (b) How and why did the military successfully increase their expenditure and compete with politicians? (c) What could be the set of reasonable explanations for the fact that the military received "budgetary protection" from presidents and Congress in a context of fierce competition for scarce resources? (d) Why did politicians agree not to compete directly with the military for a share of the budget?

The main analytical finding of this paper is that the various military agencies continue to increase their expenditure either in absolute terms or in their relative share of the total expenditure. ${ }^{4}$ The military has been enlarging its budgetary demands and expenditure and continues to be a significant political actor in the budgetary arena, suggesting that civilian control of the military remains fragile in Brazil (Zaverucha, 2000, 2005).

This finding casts new light on an ongoing academic debate on the connection between democracy and military expenditure. ${ }^{5}$ This debate is represented by two contrasting arguments. Albert Stepan (1998) has argued that military expenditure relative to Gross Domestic Product (GDP) will increase with the return to democracy. Wendy Hunter (1997) makes the opposite claim: the military capacity to compete for budgetary resources vis-à-vis politicians will be reduced within democratic settings.

Using a different data set and a more representative, democratic, selection of the period examined than that chosen by these two authors, our analysis comes closer to Stepan's and distances itself from Hunter's. ${ }^{6}$ Our analytical alignment with Stepan's is not a mere confirmation of it. We go beyond his findings and offer a new interpretation for the growth of military expenditure in Brazil under a fragile democracy.

We also go farther in that we look for the institutional mechanisms as well as the conditions that have caused an expansion of military expenditure in Brazil in this period. Stepan's counter-intuitive reasoning based on the military capacity of "lobbying effectively" is insufficient. We argue that successful competition by controlling the agenda (Moe, 2006), not lobbying effectiveness, is the key underlying causal mechanism connected to increasing military expenditure in Brazil.

The military were able to successfully protect themselves by controlling the budgetary agenda and avoiding open political conflict over their budget with other agencies. The expansion of military expenditures reflects the very particular way in which the military gets involved in politics. They are able to build a winning political strategy in budgetary games by creating an instrumental rhetoric which insists that there is a continuous threat to democratic governability. Only a strong military can defend the nation against that threat.

\section{Democratization and Military Expenditure: A Selective Review of the Literature}

This paper is organized as follows. In the first section, we will selectively review several arguments found in the literature about democratization and military 
expenditure. In the second section, we examine the basic features of Stepan's (1998) argument followed by a critique of Hunter's (1997). In the third section, we provide comparative data analysis at the ministerial level for Brazil. In the final section, we present the conclusion and the implications for the debate.

The competition for budgets among military and non-military agencies remains a crucial research problem in the study of democratic civilian control of the military. A key analytical question is: under what conditions do democracies produce more, or less, military spending when compared with non-democratic regimes?

The current agenda of research on military spending has centered on two major strands in the literature: one of these explores the connection between democracy and economic growth; the other examines the relationship between democracy and peace. ${ }^{7}$ It is generally supposed that the type of regime matters and that democracies take a negative view of military spending. Indeed, several studies have pointed out that democracies tend to produce lower military spending. ${ }^{8}$

However, comparative empirical analysis of this hypothesis shows the findings are divergent. One set of findings is closer to the "democratic peace" argument that democracies tend to spend more on social and economic policies than military ones. The other set of findings claims that the military continues to compete for expenditure with other sectors and maintains its power and influence over democracies. Thus, the type of regime is not a key variable in order to understand this relationship. It is supposed that internal conditions and political variables give a better explanation of the conditions under which democracies tend to spend less, or more, on (non-) military policies.

Fordham and Walker (2005), working on the analytical tradition of the Kantian democratic peace argument, empirically evaluate the claim that democratic states devote fewer resources to their armed forces for a large-n sample. Using indicators of the allocation of military resources and data on a wide range of states since 1816, they find empirical support for the democratic peace argument, although they consider that regime type is not necessarily the strongest influence on the allocation of resources to the military.

Goldsmith (2003), focusing on the analysis of the problem of the defense burden, shows that regime type plays a decisive role in explaining military expenditure. ${ }^{9}$ He analyzes data on more than 100 states between 1967 and 1989 to demonstrate that democracies bear lower defense burdens and spend proportionally less on defense. His argument is mainly supported by two convergent claims: one by Russett and Oneal (2001) and the other by Garfinkel (1994).

Russett and Oneal (2001), drawing upon the Latin American experience, show that states spend less on the military after democratic transition and argue that the underlying mechanism is that in a democratic system, political leaders are less inclined to use large-scale force against domestic opposition in order to ensure loyalty. Garfinkel (1994) asserts that political competition compels leaders to discount defense spending at a higher rate than leaders who feel more certain about their ability to stay in office long enough to realize the political benefits of increased military expenditure. For this reason, democracy has an inherent negative bias toward military expenditure.

The comparative analysis provided by Lebovic (2001) for Latin American democracies in the period 1974-95 suggests that the level of democracy has a significant negative effect on the size of non-military budgets relative to military ones. He suggests that the reduction of military spending in Latin American democracies 
provides support for the increasingly prevalent belief that democratic leaders in this region can strengthen their position vis-à-vis the military by drawing on the political resources afforded by democratic institutions.

Lebovic's comparative data reveal that, under democratic conditions, spending on the health and education sectors grew faster than military spending in all time periods. In the 1980s and 1990s, contests for budgets produced relatively large shifts toward military spending, especially within democracies. Although he makes this general claim about Latin America, he makes a very important differentiation for two cases: Brazil and Chile.

He points out that in the then prevailing political circumstances of Brazil and Chile, the military actually controlled the transition and permitted it to occur only after forging "foundational pacts". The transition to democracy brought with it a widely-held belief that the new democracies are beholden to military benefactors and cautious lest they themselves infringe on military prerogatives. For this reason, these democracies have little will to shift budgeting priorities in order to deal with crises, to address severe social and economic problems, or even to produce major institutional and social reforms. Their policies are thus more conducive to gridlock and sequential failures in promoting such reforms (Rezende, 2004).

Yildirim and Sezgin (2005), on the other hand, provide cross-sectional empirical tests for 92 countries during the period 1987-97 on the relationship between democracy and military expenditure. Their main comparative results confirm that a higher degree of democracy is associated with lower levels of military expenditure. Their argument is based on the idea that national military forces, under authoritarianism, are often used as an internal police force to control and repress the regime's own population rather than to protect it against external threats. In order to maintain the status quo, militarized societies may spend more of their national income on defense purposes.

Diamint (2004) makes clear that although there are no immediate risks of border confrontation in Latin America and progress has been made on weapons control, there is weak political control over the armed forces. She argues that a legislature has only a nominal capacity to monitor and veto public sector (and military) spending. The military has maintained sufficient power to buffer itself against legislative budgetary vetoes. This legislative non-oversight of military spending is a basic feature of Latin American democracies. Pion-Berlin and Trinkunas (2007) mention the "deficit attention" of defense policies in Latin America. In fact, civilian politicians tend to ignore defense policy and focus their attention instead on coup avoidance.

The coup avoidance mechanism is also mentioned by Collier and Hoeffler (2007), who analyze the relationship between military spending and the risk to governability in developing countries. They argue that governments face risks perpetrated by their own military establishments. Using both global and Africaspecific data sets, they find that, in countries with low risks to governability, governments react to this situation by cutting military spending. When this risk is high, as in Africa, governments respond by increasing such spending. Thus, there are risks to governability as a consequence of a continuous threat from the authoritarian legacy. ${ }^{10}$ These are decisive in explaining the expansion of military spending. ${ }^{11}$ 


\section{Effective Lobbying by the Military in Democratic Contexts: Stepan vs. Hunter}

Stepan (1988) analyzes military expenditure as a percentage of Gross National Product (GNP) in four bureaucratic-authoritarian regimes: Brazil, Argentina, Chile and Uruguay (1972-83). He shows that the Brazilian military lost budgetary resources under authoritarian rule. That is to say that, in contrast to the pattern presented by the other three countries, Brazilian military expenditure relative to GNP declined.

Given this empirical evidence, he had the counter-intuitive insight that with the return to democracy, military expenditure would rise and thus the military would be better off, in budgetary terms, under a democracy. The main reason for Stepan's argument is that "the military as institution could more effectively lobby for their legitimate needs if the military as government were not in office" (Stepan, 1988: 72).

Although suggestive and relevant, this argument is insufficient for two basic reasons. First, Stepan does not explain how and under which conditions this would happen. He suggests no causal mechanisms that would lead to his envisioned outcome. Second, there is no guarantee per se that the return to democracy would automatically produce a positive effect on military expenditure. ${ }^{12}$ Furthermore, the empirical evidence provided by Stepan is restricted to military regimes. Therefore, our article seeks to fill these two gaps by analyzing the democratic governments of Fernando Henrique Cardoso (FHC) and Luís Inácio da Silva (Lula).

Stepan's counter-intuitive insight is based on analyzing military expenditure relative to GDP. This indicator measures exclusively the weight of military expenditure on the national economy without taking into consideration two other important indicators: (a) absolute military expenditure, namely the gain (or loss) of military expenditure over time; and (b) the military's share in overall expenditure, i.e. the proportion of military expenditure in total public expenditure (military and non-military). These two indicators are crucial to an understanding of military power vis-à-vis civilian power in the distribution of budget resources. In our analysis, we take into consideration these two indicators and, unlike Stepan, we avoid using military expenditure relative to GDP.

Comparing the annual values (1972-83) of expenditure on the armed forces relative to GDP for the four countries of the Southern Cone, Stepan concludes that the Brazilian military suffered the highest absolute budgetary losses in comparison with the other three countries, given that Brazil's military expenditure declined from 1.4 to $0.7 \%$ in this period. In contrast, Argentina's increased from 1.4 to $2.7 \%$; Chile's went from 2.3 to $4.5 \%$; and Uruguay's moved from 2.4 to $3.3 \%$ (Stepan, 1988: 73). Nonetheless, these figures per se do not demonstrate that absolute military expenditure declined in Brazil, because the GDP growth rate in the period was much more accelerated in Brazil than in the other three countries. Moreover, the intensity of the absolute GDP growth may also reduce the weight of military expenditure in the national economy. Indeed, the average annual growth rate of GDP for these cases shows that Brazil reached 5.22\%, much higher than Argentina, Chile, and Uruguay (at $1.62 \%, 1.45 \%$, and $1.36 \%$, respectively). This accelerated growth in Brazil pushed the share of military expenditure in Brazil even farther downwards. 
TABLE 1. GDP Annual Growth Rate (\%) (1972-1983) Brazil, Argentina, Chile and Uruguay

\begin{tabular}{lrrrc}
\hline & Brazil & Argentina & Chile & Uruguay \\
\hline 1972 & 13.90 & 6.12 & -3.62 & 0.90 \\
1973 & 9.78 & 6.50 & 4.09 & 1.59 \\
1974 & 5.69 & -1.40 & -12.89 & 3.62 \\
1975 & 9.20 & -2.90 & 3.49 & 2.79 \\
1976 & 4.90 & 7.17 & 9.86 & 3.36 \\
1977 & 5.00 & -2.51 & 8.22 & 3.91 \\
1978 & 6.80 & 7.81 & 8.27 & 6.19 \\
1979 & 9.20 & 2.21 & 7.95 & 6.02 \\
1980 & -4.40 & -5.74 & 5.37 & 1.95 \\
1981 & 0.70 & -3.15 & -14.09 & -9.45 \\
1982 & -3.40 & 3.73 & -0.71 & -5.86 \\
1983 & 5.22 & 1.62 & 1.45 & 1.36 \\
Average & 5.22 & 1.62 & 1.45 & 1.36 \\
\hline
\end{tabular}

Source: Oxford Latin American Historical Database.

\section{Hunter's Argument}

The comparative analysis of the competition for budgets under democracy in Brazil is widely influenced by Hunter (1997). She combines rational choice and historical institutionalism to explain civil-military relations within budgetary decisions in post-authoritarian contexts. Her claim is that the emergence of and the movement towards electoral democracy results in a reduction of budgetary resources to the military sectors. She says, "at the risk of exaggeration, conditions of the 1980s and 1990s have rendered the Brazilian military somewhat of a paper tiger." Thus she expected that, over time, military agencies would lose power and democracy would prevail. ${ }^{13}$ Being politically weak, the military should lose out in its share of the budget pie. Priorities would be changed and soldiers would not compete for budgetary resources with politicians, who would have the power to distribute resources for social and economic policies.

Her historical observation leads to the supposition that rational politicians in democratizing nations act to expand budgetary levels for non-military sectors. Politicians are primarily driven to thinking of the electoral returns to themselves and this depends largely on how they are able to increase spending levels on nonmilitary matters. Their prime interest is to enlarge their electoral constituencies through patronage. Thus, politicians need national budgetary resources to distribute among their constituents. During the authoritarian regime, she argued, the military budget was shielded from legislative interference. With democracy this safeguard is removed and, consequently, politicians try to encroach on the military's share of the budget.

Then she asserts, "in a dynamic and competitive political context in which politicians must respond to a myriad of factors other than military pressures, military prerogatives do not necessarily translate into effective influence over policy outcomes" (Hunter, 1997: 71). Therefore, according to her reasoning, the defense budget should decrease because: (1) It is in legislators' best interest to transfer previous allocations from defense to other civilian programs. Even if this 
behavior may threaten political stability and lead to a military coup, strong resistance to the idea of collective action leads them to think only in particularistic terms. Lack of trust among legislators is rampant, and they are afraid of the emergence of free-riders, that is to say, those who will take unfair advantage of distributive policies that lend themselves to patronage politics. These "smart" politicians will be re-elected and also enjoy the stability acquired by those who rejected clientelism but were not re-elected. (2) Therefore, by default, the military will not be a strong contender for state funds in the post-authoritarian period.

Looking at the last period of democracy in Brazil (1945-64), Hunter (1997: 98) concluded: "the Brazilian armed forces suffer from a paucity of resources that can be exchanged for votes. At the same time, certain civilian ministries - such as transportation, education, health and agriculture - are highly suited for this purpose." Then she borrowed a chart from Ames (1987) showing that the share of the military in budgets over the above mentioned period had decreased. She believes that this chart supports her theoretical prediction. And given historical precedent, the expectation is that this pattern will continue, especially since Congressional control over the budget increased with the Constitution of 1988 .

This conclusion, however, presents four flaws:

- It is not enough just to show that the military's share of the budget decreased in that period. It is necessary to compare this decrease with the amount of other budget allocations. Although it is true that the military's share decreased in the above mentioned period of time, it still received a greater budget share than that assigned to education, housing, and sewage treatment. When compared to Public Works in that period, the record is mixed: during some years the military's budget share was higher and in others lower.

- Furthermore, whether this was a period of "democracy" may be questioned. Immediately after President Jânio Quadros's resignation (1961), Vice-President João Goulart could not assume office immediately with full powers, given objections by the military. A Parliamentary Amendment was passed reining in Goulart's prerogatives (Cohen, 1994). Only thereafter was Goulart sworn in. It is hard to define this period (1961-4) as democratic even using subminimalist standards. ${ }^{14}$

- The decrease in the military's share of the budget does not automatically mean a victory for the civilians, and vice-versa. The decrease could be due to economic difficulties which affected the national budget in absolute terms. In this case, an analysis of how the burden was absorbed among different political actors must be conducted to be sure of the significance of the decrease.

- Hunter compared a period of almost twenty years (1945-64) with just two years of the Collor presidency. ${ }^{15}$ Moreover, Collor was accused of corruption and not even able to complete his tenure of office. Nor does Hunter take into consideration some particularities of Collor's personality. He was unhappy with the military given that pieces of information were leaked to the press, during the presidential election, about his private life, and consequently he started his government in a spirit of revenge. His actions should rather be seen as a vendetta which aimed at establishing civilian control over the military. As soon as he perceived that the impeachment process was making progress, he opened the state coffers and tried to cajole the military into supporting him, hoping that they would exert pressure on Congress. ${ }^{16}$ But it was too late, and his maneuver failed. Then, as soon as Vice-President Itamar 
Franco replaced Collor as President, the military's budget share began to increase (Zaverucha, 2000) and Franco allotted nine cabinet posts to the military. However, this period was not taken into consideration by Hunter, leading her to derive the wrong conclusion about the relationship between the military's budget share and electoral democracy. She took the tree for the forest: a typical case of metonymy.

- In Brazil, contrary to the United States, implementation of the budget approved is not mandatory but optional. In fact, implementing an approved budget is a fiction. ${ }^{17}$ The Executive does not need to follow what was approved by Congress. This prerogative enhances the authority of the Executive, who negotiates the allocation of funds with individual politicians rather than with political parties and who can withhold or increase previous allocations determined by Congress. Researchers must thus examine what was really implemented rather than what was formally approved. Figures provided by Hunter for the period (1945-64) do not make this crucial distinction.

- Even if the formal budget were to be trusted, it is worth pointing out that the participation of Congress in the process of crafting the military budget is negligible (Limongi and Figueiredo, 2002). That is to say, the values are previously negotiated between the President, the Defense Minister and the military commanders and then sent to Congress. Legislators then rubber-stamp them. Therefore, as Zaverucha (2005) argues, congressmen have considerably less power to encroach on the military budget than Hunter expected.

Thus neither Stepan nor Hunter has explored the key variables for explaining when the military will be able to continue to expand its budget. Neither gives sufficient attention to the key institutional variable of "no formal veto" for both the Executive and the Legislature over the military budget. The levels of budget for the military are decided on during an informal bargaining process between the President, who is constitutionally the Armed Forces Commander-in-Chief, and the military top brass. This is different from the other ministerial agencies, which have their proposals open to vetoes from the politicians in the legislative process. The military are able to use the President politically to keep their levels of resources safe in the budgetary games. The military's strategy for competing for higher levels of spending is by agenda control and not insulation. The military keeps its budgets up in Congress "not by winning conflict against opponents, but by using an agenda control to keep conflictual alternatives off the table entirely" (Moe, 2006: 59). This outcome helps to maintain the stability of civil-military relations in Congress.

Controlling the budgetary agenda, the military assume strategically the position of guardians of the status quo (McSherry, 1997). They bargain with the politicians for the maintenance of authoritarian enclaves. Deepening democracy, in the sense of abolishing those enclaves, is seen by the High Military Command as bringing a high probability of disturbing the established political equilibrium. ${ }^{18}$ This entails an opportunity for an institutional retrocession. ${ }^{19}$ Such is the logic underlying political-military bargaining over the budgets.

This bargaining strategy is much enhanced as conservative politicians become reactive to non-democratic behavior from the opposition, which leads to a willingness to collude with the military so that the latter assume the role of guardians for the purpose of maintaining governability. Thus the variable of "internal political risk" has a central position in explaining the Brazilian case. 


\section{Patterns Analysis of Comparative Data: The "Real Tigers" and the Expansion of Spending}

In this section we present and analyze the data. We will focus on the longitudinal and compositional variation of federal spending of 24 ministries for the FHC I and II and Lula administrations. ${ }^{20}$ In order to meet the purposes of this article, these ministries will be divided into two main clusters: high and low spenders. The high spenders are the six ministries of Social Security, Health, Defense, Education, Labor, and the Treasury as they account for more than $80 \%$ of ministerial spending over all administrations.

The analysis of expenditure patterns of the high spender cluster is our principal focus. In examining this group, we will pay special attention to Defense in order to understand if the military have maintained, expanded, or reduced their levels of spending with the movement towards democracy under the prevailing circumstances in Brazil.

The first analytical endeavor of this paper is to show the differential patterns of the expansion of spending exhibited by ministries since the FHC administration. The analysis will attempt to show that democratization contributed to an accelerated expansion of spending; explain how this expansion differently affected the spending patterns of high and low spenders; and, more importantly, show how this in turn affected the military's behavior with respect to spending. We will question whether democratization was accompanied in Brazil by an increase in competition among the ministries over resources, and whether the military continued to behave as a keen competitor for larger portions of federal spending.

The increasing competition for federal resources between ministries is a reality for Brazilian democracy. As can be seen from the data in Table 2, there has been a sharp rise in average spending by all groups of ministries since 1995, revealing a consistent pattern over time: the continued expansion of federal spending. Democratization has been accompanied by increasing pressures from budgetary demands for programs and projects at the ministerial level. Over the years under study, ministries, especially the high spenders, saw a considerable swelling of their annual spending, which jumped from $\mathrm{R} \$ 248$ billion to $\mathrm{R} \$ 665$

TABLE 2. Expenditure by Ministry* by FHC and Lula Administration, R\$ billion at 2006 prices

\begin{tabular}{lrrrrc}
\hline Ministry & FHCI & FHC II & Lula & FHCI - LULA & Variation (\%) \\
\hline Social security & 104 & 172 & 291 & 187 & 179 \\
Health & 34 & 51 & 80 & 46 & 132 \\
Defense & 31 & 49 & 65 & 34 & 111 \\
Education & 20 & 29 & 41 & 21 & 102 \\
Labor & 15 & 24 & 59 & 43 & 287 \\
Treasury & 13 & 17 & 21 & 8 & 60 \\
Total high spenders (6 ministries) & 218 & 342 & 556 & 338 & 155 \\
Total low spenders (18 ministries) & 30 & 41 & 109 & 79 & 265 \\
Total expenditure & 248 & 384 & 665 & 417 & 168 \\
\hline
\end{tabular}

Note: *Average value for each administration.

Source: Ministry of Planning, Budget and Management. 
billion during the FHC and Lula administrations. The case of Brazil is better understood as a particular one in which democracy is connected with strong expansion and fierce competition for resources.

The expansion of federal spending was highly concentrated in the "high spender" cluster. More than $80 \%$ of spending was concentrated in one-fourth of the total number of federal ministries. The participation of Defense in this group is the first strong evidence that the military actors have continued to be strong competitors in the political arena for budget share. They, as we will show later, do not lose power despite strongly competing bids by other high spenders, even when there is heavy pressure for redistribution via social spending in sectors such as Health Care and Education. A strong indication of this pattern, in addition to the expansive behavior displayed by Defense during this period, is that Defense ranked third in budgetary allocations made by the government. In the first two FHC administrations, this ministry alone received a sum total of funding higher than that received by the combined 18 ministries that comprise the "low spender" cluster. In the same period, the government allocated more resources to Defense than to traditional sectors such as Education, Labor, and the Treasury.

When we look at the cumulative sum of spending by each ministry over each administration, to indicate the total effort by the government to allocate resources in each sector (see Table 3 ), the average pattern by period is confirmed. There is strong continuous pressure for spending by the high spenders and the military follows this general pattern. The Ministry of Defense assumed third place in the federal composition of spending. Its spending level is lower only than that of the Social Security and Health Care sectors. Thus, regardless of the administration and its policy agenda, the military continue to have a very privileged position in the fierce competition for resources. This evidence clashes with Hunter's thesis, and shows that, in a democratic regime under the then prevailing circumstances in Brazil, the military conserved their strategic bargaining power over budgets and spending.

Although there was expanding pressure for spending among the ministries, comparative analysis of data on expenditure sharing suggests a clear and regular pattern in the logic of competing for federal resources. With regard to the average

TABLE 3. Total Spending by Ministry* FHC and Lula Administrations, R\$ Billion at 2006 prices

\begin{tabular}{lcrr}
\hline Ministry & FHC I & FHC II & Lula \\
\hline Social security & 417 & 688 & 1163 \\
Health & 138 & 205 & 320 \\
Defense & 124 & 194 & 262 \\
Education & 81 & 118 & 164 \\
Labor & 61 & 95 & 234 \\
Treasury & 52 & 68 & 83 \\
Total high spenders (6 ministries) & 872 & 1369 & 2226 \\
Total low spenders (18 ministries) & 119 & 166 & 435 \\
Total expenditure & 991 & 1534 & 2661 \\
\hline
\end{tabular}

Notes: * Cumulative sum of annual expenditure.

** Ministries created by Lula administration.

Source: Ministry of Planning, Budget and Management. 
TABLE 4. Expenditure Share by Ministry * FHC and Lula Administrations, $\%$ of Total Annual Expenditure

\begin{tabular}{lrrr}
\hline Ministry & FHC I & FHC II & Lula \\
\hline Social security & $42 \%$ & $45 \%$ & $44 \%$ \\
Health & $14 \%$ & $13 \%$ & $12 \%$ \\
Defense & $13 \%$ & $13 \%$ & $10 \%$ \\
Education & $8 \%$ & $8 \%$ & $6 \%$ \\
Labor & $6 \%$ & $6 \%$ & $9 \%$ \\
Treasury & $5 \%$ & $5 \%$ & $3 \%$ \\
Total high spenders (6 ministries) & $88 \%$ & $89 \%$ & $84 \%$ \\
Total low spenders (18 ministries) & $12 \%$ & $11 \%$ & $16 \%$ \\
Total expenditure share & $100 \%$ & $100 \%$ & $100 \%$ \\
\hline
\end{tabular}

Note: *Average share of expenditure for each administration.

Source: Ministry of Planning, Budget and Management. Several years.

value of share for each administration, the data presented in Table 4 suggest that the high spenders received approximately $85 \%$ of federal expenditure. This amount is distributed according to a regular pattern for all administrations: more than $60 \%$ of the total amount is distributed to Social Security, Health, and Defense. Defense maintains its power in the political struggle and has received resources that are very close to the levels of the Health care sector and superior to the amount received by Education. This again confirms that the democratic regime aggressively supported bids for military expenditure despite the competing bids for money of sectors closely linked to the production of social redistribution and inclusion, such as Education and Health.

Longitudinal analysis of the variation of ministerial spending in the transitions of the governments allows us to understand the particular dynamics by which the Brazilian ministries expand or maintain their spending power. Does a change in government alter the levels of spending? If so, which sectors are affected by these changes? Table 5 presents this data for the two transitions: from the first to the second FHC; and, from FHC to Lula. In overall terms, the data indicate a tendency of the ministries to increase their expenditure. There was a movement towards an aggressive expansion of $\mathrm{R} \$ 136$ billion from the first transition and this was even stronger in the transition from FHC II to LULA, amounting to $\mathrm{R} \$ 282$ billion. For the high spenders group, these variations were from $\mathrm{R} \$ 124$ billion to $\mathrm{R} \$ 214$ billion.

Examined more closely, the variations for the ministries in the high spender cluster suggest that the social sectors were the ones mainly responsible for the sharpest expansions, but that this occurred along with strong conservation of the Defense and the Treasury sectors. This reveals a very interesting pattern of social expansion-cum-preservation of the military's power within democratization in Brazil. Comparing the ranking of the absolute variations among the ministries, Social Security continued to be the ministry with the most marked expansions for the two transitions: $\mathrm{R} \$ 68$ billion for FHC I to FHC II and $\mathrm{R} \$ 119$ billion from FHC II to Lula. The Ministry of Defense ranked second in terms of the largest variations in the first transition among administrations, and lost its power in the second transition. The Labor Ministry was the ministry with the second largest variation in the second transition. 
TABLE 5. Variation of Expenditure by Ministry*

FHC and Lula Administrations R\$Billion at 2006 prices

\begin{tabular}{lcc}
\hline Ministry & FHC I to FHC II & FHC II to Lula \\
\hline Social security & 68 & 119 \\
Health & 17 & 29 \\
Defense & 18 & 17 \\
Education & 9 & 12 \\
Labor & 9 & 35 \\
Treasury & 4 & 4 \\
Total high expenditure (6 ministries) & 124 & 214 \\
Total low spenders (18 ministries) & 12 & 67 \\
Total expenditure & 136 & 282 \\
\hline
\end{tabular}

Notes: * Average expenditure for each administration.

** Ministries created by Lula administration.

Source: Ministry of Planning, Budget and Management. Several years.

TABle 6. Expenditure by Ministry

FHC I to II and Lula Initial and Final Years of each Administration $R \$$ Billion at 2006 prices

\begin{tabular}{lrrrrrrrrr}
\hline & \multicolumn{2}{c}{ FHCI } & & \multicolumn{2}{c}{ FHC II } & & \multicolumn{2}{c}{ Lula } \\
High Spenders & 1995 & 1998 & & 1999 & 2002 & & 2003 & 2006 \\
\hline Social security & 83 & 124 & & 139 & 210 & & 231 & 352 \\
Health & 31 & 37 & & 43 & 60 & & 64 & 93 \\
Defense & 28 & 35 & & 38 & 59 & & 59 & 76 \\
Labor & 12 & 17 & & 18 & 32 & & 44 & 69 \\
Education & 20 & 22 & & 24 & 35 & & 38 & 46 \\
Treasury & 9 & 14 & & 16 & 19 & & 21 & 22 \\
Total expenditure (High spenders) & 183 & 250 & & 277 & 414 & & 457 & 658 \\
\hline
\end{tabular}

Source: Ministry of Planning, Budget and Management. Several years.

The evolution of absolute spending for the initial and final years of each administration is shown in Table 6 . For all the periods, the high spender cluster had a more intense expansion of spending, which, at the beginning of FHC I in 1995 , was $\mathrm{R} \$ 183$ billion, and at the end of the Lula administration, was around $\mathrm{R} \$ 658$ billion. The spending by this group grew by more than 3.5 times, while that of the Ministry of Defense grew by 2.8 times. In comparative terms, the Defense sector appears as the third spending priority of the government, being inferior only to the levels of Social Security and Health for all the periods considered in the analysis.

The evolution of the annual expenditure for the Ministry of Defense for the years 1995 to 2006 is shown in Figure I. The line indicates a strong and accelerated expansion of the expenditure on the military for all the administrations. There is little evidence to the contrary. This does not confirm the hypothesis that the military lost their political power to compete for expenditure with other sectors nor even that their expenditure levels were reduced over time. Democratization 


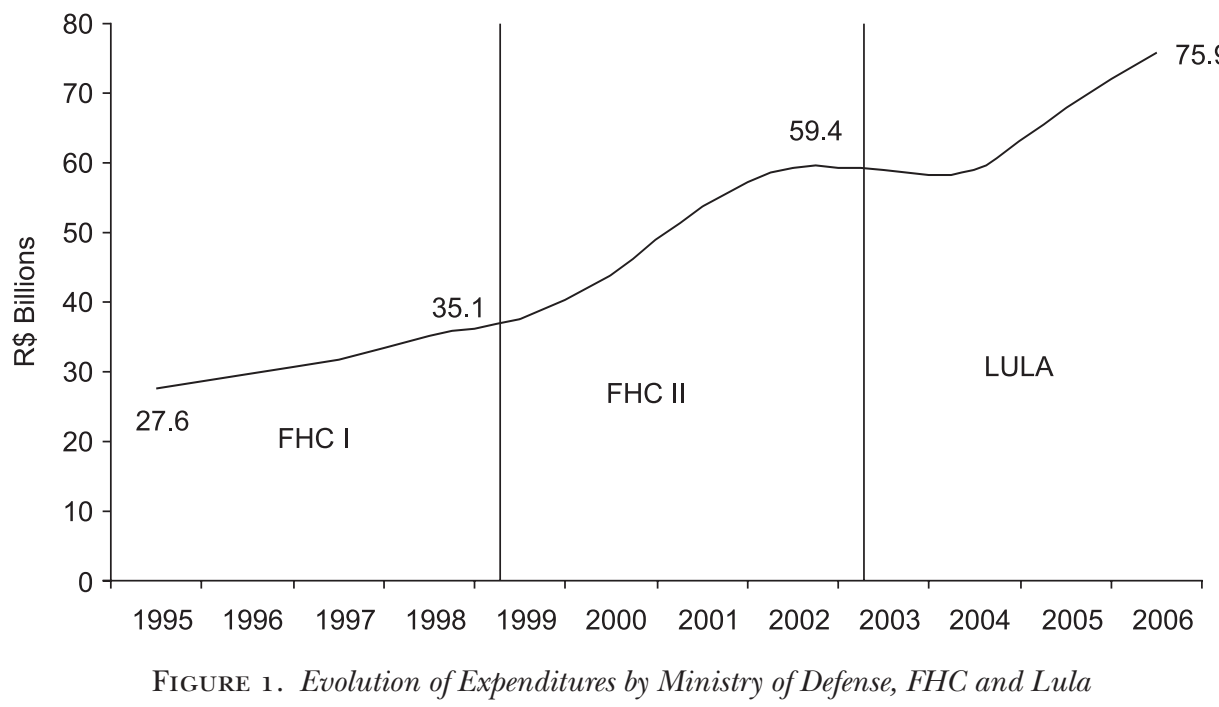

Source: Ministry of Planning, Budget and Management. Authors' elaboration.

was followed, in the Brazilian conditions, by a massive effort to maintain the power of the military and not the contrary. The real challenge is to explain how the military conserved their power and made their demands for a share of the budget feasible within democratic competition. The data in this Figure allow it to be said that all governments followed a pattern of meeting the increasing demands of Defense for expanding expenditure. In a very surprising way, in the political competition for scarce resources, the Ministry of Defense was not affected by any real attempt to control or reduce their level of spending.

The competition for resources among the high spender cluster is shown by the comparative figures presented in Figure 2. The data suggest a pattern of accelerated expansion: the ministries in this cluster more than doubled their levels of expenditure. However, there is a clear differentiation in the acceleration rates. Social Security and Labor, especially in the Lula administration, were the two key sectors responsible for the expansion of federal spending. There is a clear movement to combine democracy with social spending. However, this was done while conserving the power of the military, which was not expected by authors such as Hunter. In fact, the Ministry of Defense had an expansionary pattern that was not excessively accelerated but whose patterns were quite close to those of Health, Education, and Treasury, indicating that the military did not lose their power with the advent of democratization, Brazilian-style.

Figure 3 shows the comparative evolution of the Labor, Social Security, and Defense Ministries. The data indicate the conservation of the expansive spending patterns of the military over time. The evolutions are quite close to each other until the end of FHC II in 2002. With the beginning of the first Lula administration, it is possible to suggest a change in the expansionary patterns. Labor and Social Security had a very strong expansion almost doubling their spending in relation to 2002. However, the military continued to expand more steadily and to maintain their levels of spending. Thus whichever indices we use, there is no clear sign 


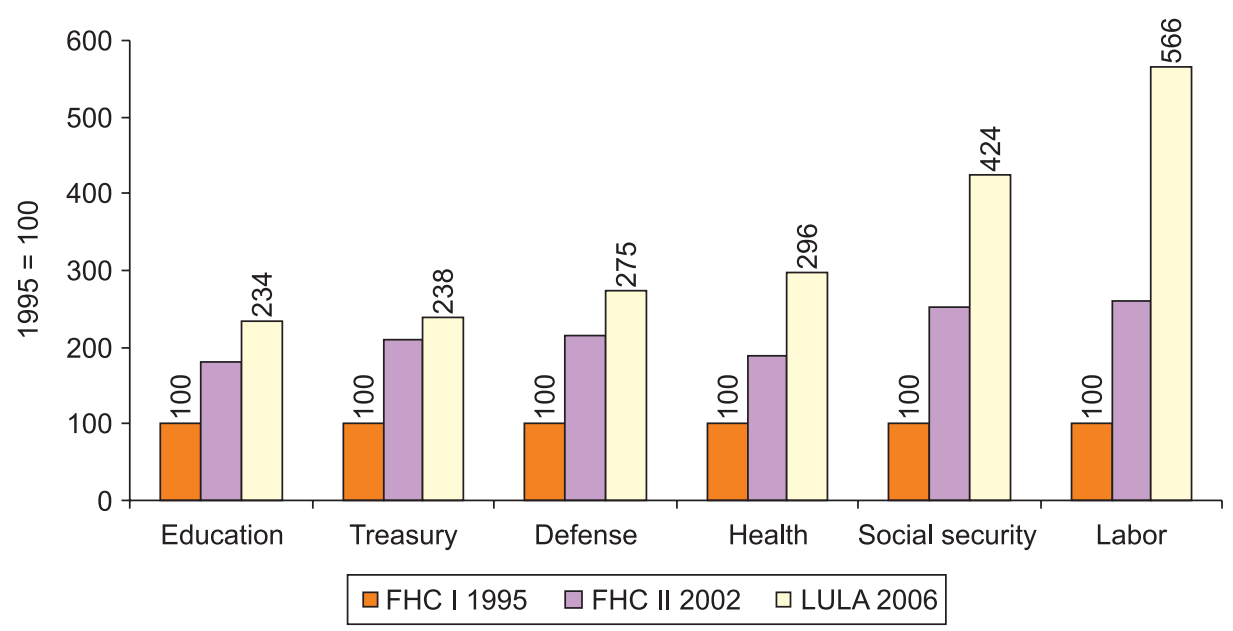

FigURE 2. Comparative Evolution of Expenditures by Ministry High Spenders FHC I, FCH II and Lula

Source: Ministry of Planning, Budget and Management. Authors' elaboration.

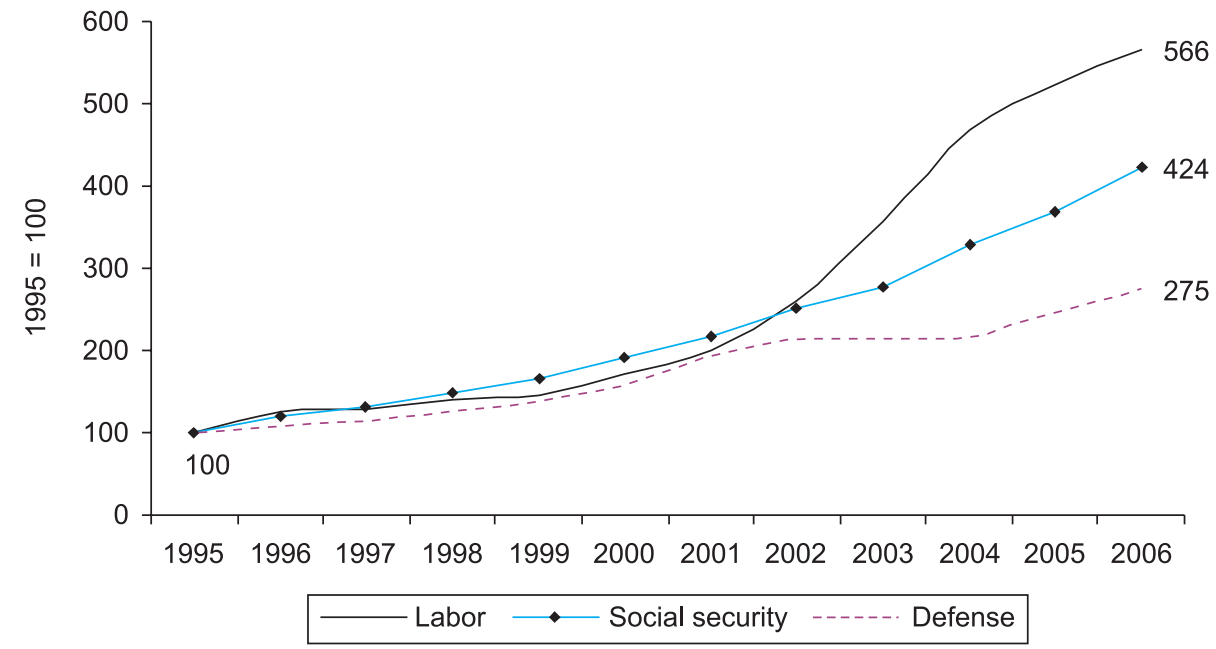

FIGURE 3. Comparative Evolution of Expenditure by Labor, Social Security and Defense FHC I, FHC II and Lula

Source: Ministry of Planning, Budget and Management. Authors' elaboration.

of a reduction of military spending levels under democratization in Brazil. The armed forces continue to be a powerful actor in the budgetary arena. The next step in this analysis, given in the following section, is to provide an explanation for these new and intriguing data. 


\section{Agenda Control and the Expansion of Military Spending in Brazil}

Explaining the expansion of a military budget usually focuses on one or more of three clusters of variables: institutional, systemic, and agential. In this paper, we are offering an institutional explanation in which the "no-veto" variable reflects the rules of the bargaining game over budgets in the Brazilian democracy. This is to say that, although other variables are relevant, in the Brazilian conditions the institutional design plays an active role in explaining the expansion of military expenditure following democratization. For this reason, this article gives special attention to the explanatory power of the way the President, the Congress, and the military interact strategically over the definition of the budget and spending levels.

Choosing an institutional variable, however, does not exclude the possibility that other systemic and agential variables can play decisive roles in other conditions and in other explanations. The systemic variables are not considered here as pivotal because Brazil has particular features that differ from other developing nations such as China and India, where international factors have strongly influenced military spending. (During the period of analysis, China became an important global player by having a seat on the UN Security Council, and India had serious disputes with Pakistan.) Brazil, on the contrary, does not face major regional conflicts in South America.

In fact, the military in Brazil faces the dilemma of not having a clear external enemy to fight against. This reduces the appeals they can make in order to purchase new weapons. To justify their budgetary resources under democratic conditions, they have to perform internal roles such as policing, drug traffic control, commercial aviation control, merchant marine control, road construction, etc. The fact is that around $75 \%$ of the military budget is spent on personnel and salaries (Heye, 2005). Given that external factors do not play a considerable role in explaining military expenditure, examining the way the military strategically deals with politics and politicians offers greater explanatory power.

The particular institutional design that links the Executive-Legislative relationship in Brazil helps explain the ability of the political actors to control (or not) the military's budget bids. The electoral and political game influences how and under what conditions the Executive, the Legislature, and the military collude to control resources, and the condition of no-veto makes it possible for the military to play a winning strategy of controlling the agenda. Agenda control is the key underlying mechanism that can explain the active involvement of the military in politics during the FHC and Lula administrations.

Brazil does not follow the path of civil-military relationship suggested by Feaver (2005). He makes the claim that civilian agencies may punish military ones by cutting the budget. In the case of Brazil, given the strategic exchange between the President, Congress and the military, politicians do not have the clout to shrink military expenditure, mainly for fear of the outcome of a political equilibrium breakdown. Instead, they have rewarded the military as the "guardians" either by maintaining their budgetary level or by expanding it. This outcome is consistent with Collier and Hoffler (2007) as well as with the arguments of Pion-Berlin and Trinkunas (2007) regarding the explanatory power of a coup avoidance mechanism.

The variable of internal political risk provides a better explanation because, in Brazil, there is considerable internal threat and a low level of external threat (Desch, 1999). ${ }^{21}$ As suggested by Collier and Hoeffler (2007), causal mechanisms 
such as leadership, and the perception of threat from an adversary, based either on real or on subjective judgment, matter. This means that as soon as conservatives think that the progressive group remains, even if only partially, a revolutionary group and that the progressives' adhesion to democracy is instrumental, they strive to maintain a privileged relationship with the military, trusting that this close link can be converted into active support whenever necessary (Alexander, 2002).

This type of explanation works well for the Brazilian case, where presidents have to depend on the military to govern, regardless of their policy and ideological agenda. The perceived threat to leadership, and internal conflicts, are usually augmented by military authorities, which leads to presidents spending more on military bureaucracies and personnel.

Two facts show that conservative forces fear the implementation of radical non-democratic policies in Brazil. The first evidence for this is linked to how the military elites are trained in values. The second one is related to fear about the lack of loyalty of radical leftist groups to Brazilian democratic governability and policies.

Military elites in Brazil are strongly inculcated with the belief that there are always internal forces willing to install a Marxist-Leninist type of government in Brazil. Amaral's study of the curriculum of the courses taught in the School for the Brazilian Army High Command (Escola de Comando e Estado-Maior do Exército Brasileiro - ECEME), the most accredited military educational institution, revealed that the notion of an "internal enemy" still persists in training on values (Amaral, 2007). It is a concept that was widely used by the National Security Doctrine (Doutrina de Segurança Nacional) during the authoritarian regime in Brazil. Recently the new concept of "adversarial forces" (forças adversas) has been substituted for "internal enemy" but the idea is the same.

This is a key concept in the course on Guaranteeing Law and Order (Garantia da Lei e da Ordem - GLO; see Table 7). ${ }^{22}$ In this course, the military study how to combat revolutionary adversarial forces, i.e, those forces which do not accept the rules of the democratic game in Brazil. In the Internal Security course, the military discuss at length concepts such as subversion and armed struggle. The military are taught: (a) to understand the causes, characteristics, and purposes of revolutionary movements; and (b) to identify the groups, movements, entities, and organizations that have the potential to become revolutionary adversarial forces. This means that the military still perceives that left-wing radical groups may launch a Marxist-Leninist revolution. This enhances the role of the military as guardians of the status quo.

This is not to say that groups on the left do not provide ample rhetorical fodder for the fears of the right. One of the main adversarial groups perceived by the military is the Landless Movement (Movimento dos Sem-Terra - MST). During a recent interview, João Pedro Stédile, one of the main leaders of this movement, declared that the masses will speak out and that "the Right needs to count on a strong government capable of repressing". According to him, the MST has a million people on the roadsides: they are "our army who can be mobilized at any time" (Carta Capital magazine, September 21 2005).

Another MST national leader, Jaime Amorim, mentioned the real possibility of resorting to armed struggle as a way to defeat the incumbent government. Amorim's ideological main references are Marx, Lenin, Che Guevara, Zapata, and Mao-Tse Tung, among others. He claimed that "Chiapas only become a 
Table 7. Escola de Comando do Estado - Maior do Exército (ECEME) Curriculum Hours - 2006

\begin{tabular}{lrr}
\hline Course & Hours & \multicolumn{1}{c}{$\%$} \\
\hline Army field operations & 1024 & $43.3 \%$ \\
Logistics and mobilization & 333 & $14.1 \%$ \\
Strategy & 178 & $7.5 \%$ \\
Guaranteeing law and order (GLO) & 170 & $7.2 \%$ \\
General staff services & 101 & $4.3 \%$ \\
Physical military training & 92 & $3.9 \%$ \\
Managerial sciences & 90 & $3.8 \%$ \\
Military history & 86 & $3.6 \%$ \\
Foreign languages & 60 & $2.5 \%$ \\
Military intelligence & 39 & $1.7 \%$ \\
Social communication & 32 & $1.4 \%$ \\
Science and technology & 31 & $1.3 \%$ \\
Teaching methods & 25 & $1.1 \%$ \\
Politics & 23 & $1.0 \%$ \\
Economics & 22 & $0.9 \%$ \\
Research methods & 21 & $0.9 \%$ \\
Law & 20 & $0.8 \%$ \\
Military leadership & 16 & $0.7 \%$ \\
Total & 2363 & $100.0 \%$ \\
\hline
\end{tabular}

reference because an armed struggle is adapted" (Veja, July 101998 - Apelo à Luta Armada, Interview).

It is not only the Armed Forces who hold this perception of the MST. Some members of the Public Ministry (Ministério Público - MP) also share it. For instance, in July, the Public Ministry of Rio Grande do Sul State indicted eight members of the MST, and applied the National Security Law (Lei de Segurança Nacional - LSN).$^{23}$ They were accused of an illegal invasion of private rural property in Rio Grande do Sul State. The attorney Gilberto Thums justified the use of LSN, arguing that "the MST has been acting not only as a social movement, but as a political movement, adopting guerrilla techniques [...] MST is in the second stage of guerrilla organization, as it makes use of sabotage acts. In Porto Alegre, for example, they invaded supermarkets [...] We observe that the MST is adopting a technique that goes beyond social movements' purposes and goals" (Uchinaka, 2008).

Furthermore, leftist movements do sometimes move from rhetoric to action. Land invasions have been organized by the MST, the Roofless Movement (Movimento Sem-Teto) has occupied public buildings; and politically motivated strikes have been held by Military Police personnel, especially low-ranking soldiers. Such activities have produced distrustfulness throughout conservative sectors, who are ready to rise up against any risk of the market-driven economy being dismantled. In such a context, the culture of fear runs counter to democratization, as it leads to feelings of distrust among political actors, instead of cooperation. The fearful are inclined to look for safety of the kind provided by an armed power and this in turn leads conservative political actors to agree to significant political prerogatives 
being maintained under military control, in the expectation that such arenas will naturally help preserve their interests. As recently as 2004, Senator Antonio Carlos Magalhães spoke in the Senate in favor of a salary rise for the military. He warned Lula's administration that "this wage devaluation must be compensated, having in mind that, in case of popular insubordination, the Armed Forces will be ready to defend our institutions." 24 The senator took up the topic again a few days later when he affirmed that the military are "the ones to sustain democracy." 25

In sum, Brazilian presidents devoted to democratization nevertheless attempt to keep a good relationship with coercive institutions in order to repress possible popular insubordinations, and appear to be ready, in a limited situation, to permit the suspension of democratic rights in order to maintain themselves in power. ${ }^{26}$ By the same token, the current senior military commanders will not allow non-democratic progressive groups to gain control of institutions that would pave the way for substantial changes in the political regime (Cook, 2007). The military understand the nature of this game and pursue the strategy of remaining protagonists in political, non-military arenas. In doing this, they make the overlap between military interests and society's interests more explicit.

Therefore, there is a strategic exchange in Brazil: one of budgets for governability. The military elites successfully press the government in office to expand their budget level. Given the conditions of a high level of political and institutional instability, severe income inequality and the low performance by the State in providing public services, the government's survival also depends on not reducing military expenditure. The Armed Forces may be called on to curb social unrest which threatens government stability. So, from the Executive and Legislative perspective it is better to pamper the military, thus keeping their resources safe from fierce political competition for budget resources.

\section{Conclusion}

The military have continued to expand their spending vigorously during the Brazilian re-democratization process. Brazil is an outlier; that is to say, it stands apart from the pattern expected by the democratic peace argument. The return to electoral democracy was not followed by a reduction in military expenditure. Quite to the contrary, under Brazilian-style democracy, the military continued to increase their expenditure. Indeed, there was a growth in the absolute as well as in the share of military expenditure, with Defense being maintained in third position in the ranking of federal expenditures from 1995 to 2006. This is intriguing given that the country faces huge social demands for better social policies and infrastructural services, and has not been involved in major borderline conflicts; the Ministry of Defense obtained expenditure levels exceeded only by the Social Security and Health Ministries.

The findings offered by this study allow us to align with the counter-intuitive argument provided by Stepan that the military will be better off under a democracy in terms of budgetary resources. Therefore, we distance ourselves from Hunter's argument that the military will continue to compete for expenditure with the social sectors in democratic settings. Our analysis shows that, rather than being a "paper tiger," the military still have "sharp teeth" in the budgetary arena, although for different reasons and under different mechanisms than "lobbying effectively," as suggested by Stepan. Agenda control in a presidential democracy 
plagued with inequality and fierce political competition seems to be a more realistic causal mechanism for explaining the capacity of the Brazilian military to compete successfully for a continuing high level of expenditure in Brazil.

\section{Notes}

1. The analysis of military expenditure in this paper deals exclusively with the absolute and relative variation of spending at the ministerial level. Although they are relevant, this article does not focus on how spending is undertaken by each ministry in programs and policies, nor on who exercises control over the spending and how it is made.

2. The choice of these two Brazilian presidents was made because both were fierce opponents of authoritarian rule. Their presidential agendas were mainly constructed on the rhetoric of social democracy and social redistribution. It was expected, therefore, that, when in office, they would reduce military spending significantly.

3 . The empirical analyses rely on the temporal variation of ministerial expenditure for the FHC (1995-8/1999-2002) and Lula (2003-6) administrations. We compare military spending with that of other government agencies by considering three basic measurements: (a) the relative distribution and evolution of expenditure (budget share); (b) the implementation capacity of budgetary decisions, i.e., the absolute expenditure; (c) the annual variation in expenditure. These variables allow us to show the basic regularities in the distribution of resources and the increasing demands of the military for substantially more expenditure in both administrations.

4. Comparative studies usually measure the distribution of power among government agencies using budgetary and/or expenditure allocation. The understanding of how much the military agencies effectively gain or lose in the distribution of resources in a given government is better understood using expenditure (absolute and share) as the basic indicator. In the Brazilian context, however, this indicator is the most appropriate given that the budget approved by Congress is not mandatory and agencies usually get more (or less) to spend each fiscal year than the amount previously approved as their budget by Congress.

5. Lebovic (1999) points out the potential problems when using military data to represent government priorities. In order to avoid bias and errors, he suggests determining whether military spending has increased or declined. In order to represent growth (or decline) in spending, it is reasonable to use data to express two ordinal measures: the direction of change and the ratio of this change. The direction of change is at least as important as the amount by which change has been made and may yield more accurate inferences.

6. The variation of military expenditure is examined at the ministerial level. This indicator better grasps the problem of "the effective increasing or decreasing" of (absolute, and share in) expenditure over time and can show if the military agencies spent more or less compared with other agencies, unlike the indicators used by Stepan and Hunter. The former mainly uses military expenditure relative to GDP and the latter uses budget share figures.

7. Looney (1989) argues that the analysis of the causes and consequences of militarization in developing countries has been confined to five major research problems: (a) studies of whether military spending helps or hinders economic growth; (b) analysis of budgetary trade-offs between defense and socio-economic allocations; (c) determining the factors that contribute to the successful development of arms industries; (d) identifying factors affecting the levels of arms transfers to the developing countries; and (e) examining the major determinants of the level of defense spending.

8. Although the use of military spending is a traditional measure of military power and influence in comparative research, a recent critique offered by Gifford (2006) suggests that a more fruitful possibility would be to examine both military spending and the growth of military personnel. 
9. The "defense burden problem" is concerned with explaining the relationship between military spending and GDP, i.e., the level of the presence of defense expenditure at the economic level.

10. According to Cesarini and Hite (2004: 4), "authoritarian legacies are those rules, procedures, norms, patterns, practices, dispositions, relationships, and memories originating in well-defined authoritarian experiences of the past that, as a result of specific historical configurations and/or political struggles, survive democratic transitions and intervene in the quality and practice of post-authoritarian democracies."

11. The "external threat" type of argument does not hold, due to the fact that Brazil has not been involved in major external wars since its war against Paraguay in the nineteenth century.

12. Reality is more nuanced. The military can do better or worse in budgetary terms either under democratic or under authoritarian regimes. This depends on many variables, such as the external and internal threats, economic performance, military and political cohesion, (in) correct defense and military policies, etc. (Scheetz, 2002).

13. Santos (2006: 117) has a convergent argument: "demilitarization is in progress, although going through a long, slow and peaceful process." For the same line of reasoning, see Tollefson (1995).

14. For a nice description of (sub-) minimalist standards, see Mainwaring et al. (2001).

15. President Sarney was elected vice-president by an Electoral College created by the military. Given that the President, Tancredo Neves, died before taking oath, Sarney was sworn in as President (1985-90). Unlike Sarney, Collor was elected by popular vote.

16. For example, the 1988 Constitution stipulates that salary increases should be given simultaneously to military and civil public servants. President Sarney did not respect this. Collor followed the Constitution at the beginning of his mandate but later violated it, giving a wage increase only to the military to win its support against the impeachment process.

17. For the importance of budget transparency and tools for independent monitoring, see Donadio (2005)

18. For instance, when President Lula tried, through his Civilian Defense Minister, José Viegas, to open the confidential files of the Araguaia Guerrilla War, the army's High Commander, General Francisco Albuquerque, openly spoke out against this decision. Rather than dismissing the insubordinate military commander, the President dismissed Viegas in November 2004. This choice reflects the relevance of the internal political risk variable in order to understand civil-military relations in Brazil. The nondismissal of General Albuquerque was seen by Lula as a way to avoid an institutional crisis with serious unseen consequences.

19. Institutional retrocession does not mean regime breakdown through a military coup d'état. It is understood here as a situation in which the military enhance their political power vis-à-vis civilians without taking office. For instance: forcing Ministers of Defense to leave office, increasing the scope of military justice to cover civilian matters, and/ or enlarging military constitutional powers.

20. According to customary methodological procedures, when dealing with the Brazilian time series using expenditure data, we have adjusted annual figures to $2006 \mathrm{R} \$$ prices using the official IPCA (Consumer Price Index) provided by IBGE (the Brazilian Statistics and Geographical Institute). The expenditure data were collected from the annual Execução Orçamentária do Governo Federal provided by the Planning and Budget Ministry.

21. Lula's good relationships with Presidents Hugo Chávez (Venezuela), Evo Morales (Bolivia), and Fidel Castro (Cuba) contribute to increasing conservative suspicions about his democratic commitments.

22. The GLO course is divided into four items: (a) Psychological Operations (23 hours); (b) Internal Security (49 hours); (c) Guaranteeing Law and Order Operations (91 hours); and (d) Territorial Defense (19 hours). 
23. The National Security Law (Lei de Segurança Nacional) was drawn up by the military. It is still in use by the Lula government. Although in the Legislative there are at least four proposals to abolish it, they have never reached the floor of the House. This is another major piece of evidence of non-civilian control over the military in Brazil.

24. "ACM warns about low salaries of the Armed Forces," Jornal do Senado, June 172004. The emphases are our own.

25. "ACM favors revision of the military's salaries," Jornal do Senado, June 302004.

26. In July 2003, one of the owners of the Folha de São Paulo newspaper, owing to this wave of invasions into rural and urban properties, sounded the possibility of President Lula being removed from office (Frias Filho, 2003). Also, the PSDB - Brazilian Social Democratic Party - leader in the Senate, Arthur Virgílio, compared Lula to former President Goulart (Dualibi, 2003). The same newspaper, in its July 292003 edition, published a statement by Senator Romeu Tuma in which he affirmed that, if the situation were to veer out of control, he would ask for military intervention.

\section{References}

Alexander, Gerard (2002). The Sources of Democratic Consolidation. Ithaca, NY: Cornell University Press.

Amaral, Marilea L. P. (2005). "Educação Militar Pós-1985: Os Currículos da Escola de Comando e do Estado-Maior do Exército (ECEME)," MSc Dissertation. UFPE Universidade Federal de Pernambuco. Recife.

Ames, Barry (1987). Political Survival: Politicians and Public Policy in Latin America. Berkeley: University of California Press.

Cesarini, Paola and Hite, Katherine (2004). "Introducing the Concepts of Authoritarian Legacies," in Katherine Hite and Paola Cesarini (eds), Authoritarian Legacies and Democracy in Latin America and Southern Europe. Notre Dame: University of Notre Dame Press.

Cohen, Youssef (1994). Radicals, Reformers and Reactionaries. Chicago: University of Chicago Press.

Collier, Paul and Hoeffler, Anke (2007). "Military Spending and the Risks of Coups d'Etats," Centre for the Study of African Economies, Department of Economics, Oxford University. Mimeo.

Cook, Steven A. (2007). Ruling but Not Governing: The Military and Political Development in Egypt, Algeria and Turkey. Baltimore, MD: Johns Hopkins University Press.

Desch, Michael (1999). Civilian Control of the Military: The Changing Security. Baltimore, MD: Johns Hopkins University Press.

Diamint, Rut (2004). "Security Challenges in Latin America," Bulletin of Latin American Research 23(1): 43-62.

Donadio, Marcela (org.) (2005). The Defense Budget in Latin America: The Importance of Transparency and Tools for an Independent Monitoring. Buenos Aires: SER en el 2000.

Dualibi, Juliana (2003). "Líder tucano compara Lula a Jango e diz que o governo é "fraco e arrogante'," Folha de S. Paulo, December 13.

Feaver, Peter D. (2005). Armed Servants. Cambridge, MA: Harvard University Press.

Fordham, Benjamin and Walker, Thomas C. (2005). "Kantian Liberalism, Regime Type, and Military Resource Allocation: Do Democracies Spend Less?" International Studies Quarterly 49: 141-57.

Frias Filho, Otávio (2003). "Lei e ordem," Folha de S. Paulo, July 31.

Garfinkel, Michelle R. (1994). "Domestic Politics and International Conflict," American Economic Review 84(5): 1294-309.

Gifford, Brian (2006). "Why No Trade-Off between 'Guns and Butter'? Armed Forces and Social Spending in Advanced Industrial Democracies, 1960-1993," American Journal of Sociology, 112(2): 473-509.

Goldsmith, Benjamin E. (2003). "Bearing the Defense Burden, 1886-1989: Why Spend More?" Journal of Conflict Resolution 47 (5): 551-73. 
Heye, Thomas (2005). "Os Determinantes Políticos dos Gastos Militares no Pós-Guerra Fria," PhD Dissertation. IUPERJ - Instituto Universitário de Pesquisas do Rio de Janeiro.

Hunter, Wendy (1997). Eroding Military Influence in Brazil. Chapel Hill: University of North Carolina Press.

Lebovic, James H. (1999). "Using Military Spending Data: the Complexity of Simple Inference," Journal of Peace Research 36(6): 681-97.

Lebovic, James H. (2001). "Spending Priorities and Democratic Rule in Latin America," Journal of Conflict Resolution 45(4): 427-52.

Limongi, Fernando and Figueiredo, Argelina (2002). "Em Busca do Orçamento Perdido," Insight Inteligencia (16): 145-56.

Looney, Robert E. (1989). "Internal and External Factors in Effecting Third World Military Expenditure," Journal of Peace Research 26(1): 33-46.

McSherry, J. Patrice (1997). Incomplete Transition: Military Power and Democracy in Argentina. London: St Martin's Press.

Mainwaring, Scott; Brinks, Daniel and Pérez-Liñán, Aníbal (2001). "Classifying Political Regimes in Latin America," Studies in Comparative International Development, 36(1): 37-65.

Moe, Terry M. (2006). "Power and Political Institutions," in Ian Shapiro, Stephen Skowronek, and Daniel Galvin (eds), Rethinking the Political Institutions: The State of the Art. New York: New York University Press.

Pion-Berlin, David and Trinkunas, Harold (2007). "Attention Deficits: Why Politicians Ignore Defense Policy in Latin America," Latin American Research Review 42(3): 76-100.

Rezende, Flávio da Cunha (2004). Por que falham as reformas administrativas? Rio de Janeiro: Ed. FGV.

Russett, Bruce and Oneal, John (2001). Triangulating Peace: Democracy, Interdependence, and International Organization. New York: W. W. W Norton.

Santos, Maria Helena de Castro (2004). "The Brazilian Military in Post-Democratic Transition," Revista Fuerzas Armadas Y Sociedad 3(4): 115-46.

Scheetz, Thomas (2002). "Military Expenditure and Development in Latin America," in Jurgen Brauer and J. Paul Dunne, Arming the South: The Economics of Military Expenditure, Arms Production, and Arms Trade in Developing Countries. New York: Palgrave Macmillan.

Stepan, Alfred (1988). Rethinking Military Politics: Brazil and the Southern Cone. Princeton, NJ: Princeton University Press.

Tollefson, Scott (1995). "Civil-Military Relations in Brazil: The Myth of Tutelary Democracy," LASA International Congress, manuscript.

Uchinaka, Fabiana (2008). "MST denuncia na OEA e na ONU tentativa de 'criminalização' dos sem-terra," Folha de São Paulo, 25 July.

Yildirim, Julidie and Sezgin, Selami (2005). "Democracy and Military Expenditure: a Cross-country Evidence," Transition Studies Review 12(1): 93-100.

Zaverucha, Jorge (2000). Frágil Democracia: Collor, Itamar, FHC e os Militares (1990-1998). Rio de Janeiro: Ed. Civilização Brasileira.

Zaverucha, Jorge (2005). FHC, forças armadas e polícia: entre o autoritarismo e a democracia. Rio de Janeiro : Ed. Record.

\section{Biographical Note}

Jorge Zaverucha (Ph.D in Political Science at The University of Chicago) is a Professor at the Federal University of Pernambuco where he heads the Center for Studies of Coercive Institutions and Criminality. His main area of interest is the relationship between democracy/authoritarianism and coercive institutions. His last book, "FHC, Forças Armadas e Polícia: Entre o Autoritarismo e a Democracia" was awarded the prize for Best Book on Brazil in Portuguese by the Brazil Section of the Latin American Studies Association (Montreal, 2007) 
Flávio da Cunha Rezende (Ph.D Cornell University) is a Professor of Political Science at the Federal University of Pernambuco, Brazil and a research fellow at CNPQ, Brazil. His major interests include comparative politics, research methods, and the analysis of institutional change. He is conducting a comparative research project on the determinants of the growth of public expenditures. His articles have appeared in numerous journals including Dados - Revista de Ciências Sociais, Revista de Sociologia e Política, and the International Public Management Review. His book "Why Do Administration Reforms Fail?" was published by Getúlio Vargas Foundation Press, Brazil. 